\title{
Pen Pals Are Now in Your Finger Tips- A Global Collaboration Online Project to Develop Writing Skills
}

\author{
Woon Wern Lie, Melor Md Yunus \\ Faculty of Education, Universiti Kebangsaan Malaysia, Bangi, Malaysia \\ Email: wernlie@hotmail.com, melor@ukm.edu.my
}

How to cite this paper: Lie, W. W., \& Yunus, M. M. (2018). Pen Pals Are Now in Your Finger Tips-A Global Collaboration Online Project to Develop Writing Skills. Creative Education, 9, 2491-2504. https://doi.org/10.4236/ce.2018.915188

Received: October 12, 2018

Accepted: November 13, 2018

Published: November 16, 2018

Copyright $\odot 2018$ by authors and Scientific Research Publishing Inc. This work is licensed under the Creative Commons Attribution International License (CC BY 4.0).

http://creativecommons.org/licenses/by/4.0/

\section{cc) (i) Open Access}

\begin{abstract}
Many Malaysian students have an aversion towards writing. This study explores the potential of using an online material entitled, PenPal Schools, in the English as Second Language (ESL) classroom to develop writing skill with peers around the world via an online collaborative project. A research was carried out to provide insights into the aspects of PenPal Schools that are useful in developing writing skills and to find out the potential of this material as a teaching and learning tool in writing lessons. Thirty 12 -year-old primary school students from Cheras, Selangor were chosen as the participants based on their March 2018 school based assessment writing results together with May 2018 school based midterm writing results to avoid any biasness. After the March test, they were required to join PenPal Schools and take part in the online collaborative project. The research used mixed-method design where quantitative data from pre- and post-tests and responses from semi-structured interviews were used to measure the outcome. The post test result reflected the improvement in their writing skill and it had found out that this educational website could make the writing lessons become more interesting as they could communicate and learn with peers around the world, particularly native speakers. This positive engagement in a dynamic and collaborative classroom is hoped to shed new light on the era of 4.0 education.
\end{abstract}

\section{Keywords}

Education 4.0, Pen Pals, Online Collaborative Project, Writing, English as Second Language (ESL)

\section{Introduction}

Throughout the years, Malaysian government has made a lot of effort to upgrade 
our students' English proficiency level which is eventually vital for benchmarking our country's education system against PISA (Programme for International Student Assessment) to a higher level. Efforts like strengthening the teaching of English Language via Peer Learning Community (PLC), introducing LINUS 2.0 with a wider scope to address English language literacy holistically, making it compulsory for all Malaysian students to pass SPM English starting from 2016, rolling out new and revised curricular-CEFR in both primary and secondary level etc. are of paramount importance in helping our students to achieve above global average scores as well as to fulfil the goals of language learning as stated in the Malaysia Education Blueprint 2013-2025. Undoubtedly, English is known as the international language of communication and it must be emphasized in order to help in developing competent individuals that are well versed in English so that our learners will be ready to strive for their best in the $4^{\text {th }}$ industrial revolution.

However, of all language skills, writing skill has found out to be rather difficult. This statement is further supported by Mohamad, Ghazali and Hashim (2018), where they have also stated that writing skill is an essential aspect of academic performance yet it is commonly known as a difficult area for second language learners. So, how shall we classify one as a competent writer? According to Yunus and Chien, 2016, a competent writer must have a holistic and comprehensive knowledge of grammar, use the right choice of vocabulary or phrases, understand the writing mechanics, know the organizational skills as well as having varied writing styles. Unfortunately, based on the results in PISA 2012 and 2015, it was sad to state that our Malaysian learners are still not up to the international level yet (Abdullah \& Peter, 2015). Despite many writing programmes have been introduced in Malaysia, the results are still not favourable. Moreover, Ien, Yunus and Embi (2017) also claimed that literacy is vital in preparing out pupils to achieve personal growth and even confidence in order to help them to be an effective and productive member of our society. So, it is important for educators to look for new programme like PenPal Schools to solve literacy issue.

Nevertheless, Yunus (2018) stated that in order to enable our students to become a better communicator, we should perhaps go beyond everything, be it grammar, vocabulary and pronunciation. She further elaborated that the educators should leave behind the conventional methods and try to make a difference by communicating effectively in international settings (Yunus, 2018). Subsequently, an online material entitled, PenPal School was found to match the criteria which Yunus (2018) had suggested and it was introduced in the Malaysian English as Second Language (ESL) classroom, with the hope of developing Malaysian ESL learners writing skill via an online collaborative project with peers around the world. On top of that, Yunus (2018) also stated that one of the biggest advantages of the internet for language learners is the rapid widespread availability of multiple authentic resources. This has enabled teachers to use authentic online materials when we talk about teaching. So, this paper would discuss how PenPal Schools, an authentic online material, could help in developing writing skills among ESL learners. The next section would discuss what PenPal 
Schools is all about.

\section{Brief Introduction on PenPal Schools}

PenPal Schools is a free learning website (https://www.penpalschools.com/) that is recognised globally which connects our students with students around the world to learn on certain topics via collaborative online projects. It is a global learning community which has rapidly grown to over a quarter million of students in 150 countries (PenPal Press). According to Common Sense Media, it is voted as the "Top Pick for Learning", "Top Pick for Middle School", "Top Pick for Global Education" and "Best of 2017". Quoted from the web to support the awards won, PenPal Schools is "A thoughtful, ready-to-go platform that builds global awareness and collaboration skills by facilitating authentic, cross-cultural Project Based Learning experiences". Moreover, PenPal Schools is even recognized at the White House by President Obama as one of the leading social enterprises. In 2017, it had entered the Global EdTech Startup Awards (GESA) and eventually won the third prize.

So, what do students learn in PenPal Schools? The contents of the projects span all areas, such as, human rights, fake news, robotics, joining forces for the environment, protecting the planet, a world of food, the power of art, literature etc. Each lesson will take about 30 - 45 minutes to complete. The aims include helping the learners to develop critical reading, to practise writing in a creative way, to enhance their technology or digital skills as well as to learn social-emotional skills in an authentic way. Upon getting pen pals for their collaborative project, the learners are given a certain period of time to complete some mini tasks individually. The tasks include reading some interesting articles in which glossary is provided, listening to short broadcasts and also taking part in a forum. Then, upon completing, they will be matched with learners from other countries on the matching day. After that, they will be in the same platform to complete a collaborative project. Examples of projects that they need to do are like food journal, introducing the culture in your country by recording a short video and even to organise a project to clean up the rubbish at the beach etc. Finally, they will share what they do in PenPal Schools with their peers. Then, their works will be graded and teachers could provide some reviews. Last but not least, in term of safety protocol. It is completely safe as only verified teachers and their students can join. All messages by the learners could be monitored by the teachers and all data is secure and encrypted.

\subsection{Issues in Writing}

In Malaysia, learning English at the age of seven is a must. Unfortunately, after years of learning the language, Malaysian students are still found out to be weak in English, especially in term of writing, though numerous programs have been introduced. In fact, this phenomenon is just the same as the situation in Poland. Pitura and Monika (2018) claimed that the English language activities conducted for Polish schools were not authentic and therefore could not arouse students' 
interest. Pitura and Monika (2018) further elaborated their points by stating that despite curricular officers had ensured to design a curricular with a balanced development of language competence and even with various of so-called "key competences" in learning English, it had found out that the class works conducted were still heavily focused on constructs that are tested during school-exit exams and also neglects some civic competences like group work as well as digital skills. In fact, exam-based learning, text-book based learning together with chalk and talk method are no longer suitable in this era of education 4.0. Instead, the concept of heutagogy, peeragogy and cybergogy are the main key concepts shaping 21st century learning. Thus, PenPal Schools is one of the free websites that seemed to fulfill the key concepts of education 4.0 and respond to the need of 4th industrial Revolution. In fact, this type of Computer-Assisted Language Learning (CALL) is seemed to be more and more prevalent (Yunus et al., 2013; Yunus, Salehi, \& Amini, 2016). We would further look into how education is transformed from 2.0 to 4.0 in the following section.

\subsection{Pen Pal, E-Penpal to PenPal Schools: Education 2.0, Education 3.0 to Education 4.0}

Earlier days, we have pen pals in which we regularly write and exchange letters with people we do not meet via postal mail. In fact, writing to a pen pal is one of the ways to improve English writing skills and allow teachers to have a closer look at language exchanges via a meaningful writing experience (Burk, 1989) However, if the future educators still opt for traditional type of pen pal projects, it is believed some students will feel reluctant as we must understand that most of them are generation $\mathrm{z}$ and even alpha who are claimed to be computer literate. Education 2.0 was not suitable to suit their needs as it only allows interaction between teacher and student, student and content or among students (Ajjan \& Hartshorne, 2008). Therefore, we could realise the trend has moved from conventional pen pal projects to E-penpal in which learners use email through the internet to communicate with others. This shows a shift from education 2.0 to education 3.0. Figure 1 illustrates the evolvement from Education 2.0 to Education 4.0.

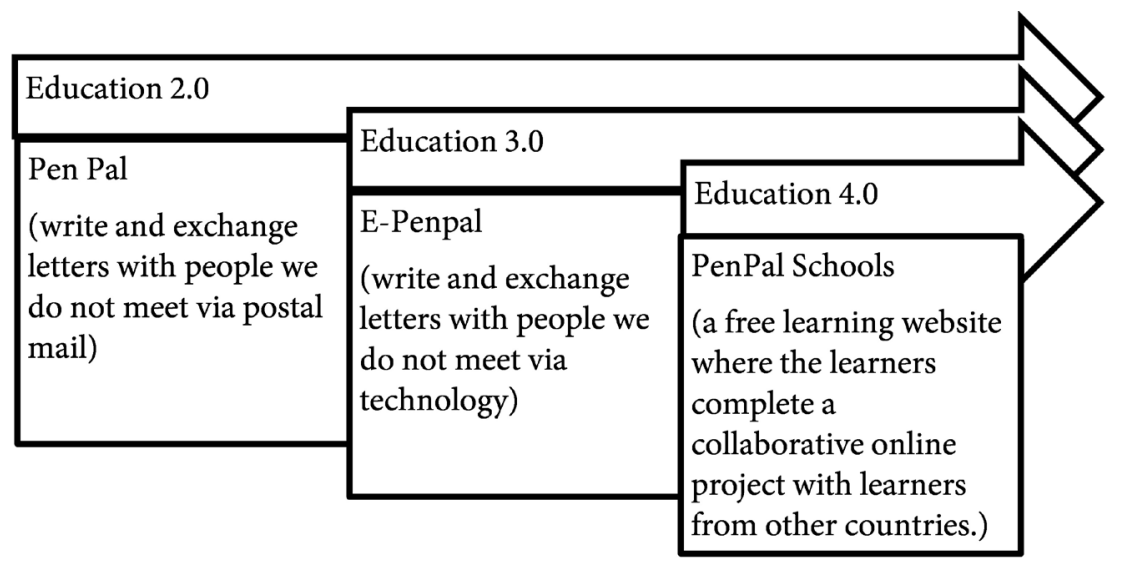

Figure 1. The evolvement from Education 2.0 to Education 4.0. 
E-penpal is one of the examples of education 3.0 in which it addressed the need as a technology society in which one writes and exchanges letters with people we do not meet via technolohgy. Puncreobutr (2016) also claimed that education 3.0 could create knowledge by supporting self-learning. According to Leapfrogging principles and context, the education in the era responding to the agrarian society is known as Education 1.0, industrial society is to be linked to Education 2.0, globalization is referred to Education 3.0 while innovation is inter-related to Education 4.0 (Austin \& Harkins, 2008). In education 3.0, it emphasized on heutagogical, a more connectivist approach to learning and teaching. It is socially constructed and contextually reinvented (Gerstein, 2014). Gerstein (2014) also stated that in the era of education 3.0, technology is everywhere and teaching can be done from various sources, be it the teachers, learners, social networks and media etc. So, the use of email in E-penpal project has helped to create a unique entity that has the potential to suit the needs of individuals and societal as well. In short, education 3.0 has helped to make the learning unique, personalized as well as helping learners to be self-determined (Gerstein, 2014).

So, with the use of PenPal Schools as one of the options in writing classroom, the paradigm has eventually shifted from education 3.0 to education 4.0. Hence, how does PenPal Schools relate to education 4.0? According to Leapfrog principles by Austin \& Harkins (2008), innovation is the main key word in era of 4.0 education. When the materials are built through selective individuals and when team-driven embodiments are in practice, especially through focused innovations, then Austin \& Harkins (2008) stated that it is education 4.0. In PenPal Schools, the learners complete a collaborative online project with learners from other countries instead of doing the projects with their classmates. So, innovation has played an essential role in this type of teaching and learning. The novelty and creativity of PenPal Schools is to modify the traditional way into a modern method without eliminating any important elements in teaching. In fact, it has rediscovered some basic approaches in ways of teaching writing too. To add on in supporting the relationship between education 4.0 and PenPal Schools, Austin \& Harkins (2008) also mentioned that education 4.0 is amplified by some positive innovation feedback loops. It is even ubiquitously and creatively available in all phases of living, learning and working (Austin \& Harkins, 2008). Puncreobutr (2016) further supported Harkins's (2008) point of view by claiming that education 4.0 is catered to the societal need in the era of innovation. Then, according to Goldie, 2016, education 4.0 is according to the changing behaviour with the special characteristics of parallelism, connectivism and even visualization. In PenPal Schools, the learners can work anytime when they are free and they will get pen pals all around the world upon completing the tasks given before the matching day. Visualisation of the look of their pen pals arouses the learners' interest and therefore it could help to optimise their learning.

Furthermore, this penpal schools learning management has helped in developing the learner's ability to apply the new technology, which will therefore help 
the learners to develop according to the changes in the society. Since the learners need to complete an online collaborative project with peers around the world, they need to be flexible. Puncreobutr (2016) also stated that the learning management in this era of education 4.0 is a new learning system. It allows the learners to grow with knowledge as well as skills for the whole life and not just merely to know how to read and write. Penpal schools provides this type of learning environment in which it helps to train the learners to be able to live in a society, to communicate with other people around the world, to create a sense of community inside and outside of the classroom as well as to equip themselves with their best ability to complete the tasks. Therefore, education 4.0 is an era more than just an education using the internet. The next section would discuss about the overview of the research methodology

\section{Research Methodology (Overview)}

This study used mixed method design in which the researcher collected both quantitative and qualitative data. The selection of the participants for this study was based on purposive sampling where 30 students from a primary school in Cheras, Selangor, Malaysia were chosen as the participants due to their low performance in March 2018 school based writing assessment. Out of these 30 students, there are 12 boys and 18 girls in which most of them (14 out of 30) score C (50 - 64 marks) in their March writing assessment. In fact, all of them understand basic English, yet, they were weak in constructing sentences or to be precise, subject verb agreement, tenses and preposition. Moreover, majority of them have strong aversion towards writing. Then, in term of data, it consisted of the comparison of results between March 2018 and May 2018 school based writing assessment, survey results from the questionnaires as well as responses by the participants from the semi-structured interviews. Some items in the questionnaire were adopted and modified from UTAUT model that was proposed by Venkatesh et al. (2003). Some changes were made which is to meet the purpose of this study and to fit the current condition of the subjects.

\subsection{Research Procedures}

30 students were selected as the participants for this study. After the school-based March 2018 writing test, they were required to join PenPal Schools and take part in the online collaborative project before the Mid Term assessment. Initially, teacher enrolled in a project and the selected participants were required to sign up for PenPal schools using the class codes given. Upon getting pen pals from other countries, the participants had to complete a few tasks given, the more active they were, the more pen pals point they would get and eventually it would help them to meet pen pals that were as active as them. On the matching days, the learners were required to complete an online collaborative project together with the peers from other countries within the time constraint given for the respective project ( 1 week). After that, the teacher would evaluate the students' 
works and comment on their works if necessary. Figure 2 illustrates the research procedures of PenPal Schools. After the school based midterm assessment (May, 2018), the writing results between March 2018 and May 2018 were being compared. Last but not least, the participants were required to complete a survey form at https://polldaddy.com. The next section would discuss about the data collection as well as data analysis.

\subsection{Data Collection and Data Analysis}

The main data collected was the participants' writing results in both March 2018 and May 2018 School based writing assessment. Comparison was made and this was to check whether any improvement on the writing results occurs. Then, a survey form based on UTAUT model was created and all participants were required to complete the survey form online at https://polldaddy.com. The data from the questionnaires were statically analysed using frequency counts and percentage distribution. A semi-structured interview with the participants was being carried out to check out the potential of using PenPal Schools in ESL writing classroom. All names reported were pseudonyms. The next unit would further elaborate on the findings and discussions.

\section{Findings and Discussions}

The findings would be discussed based on three main sections, which are the comparison of results between March 2018 and May 2018 school based writing assessment, survey results from the questionnaires as well as responses by the participants from the semi-structured interviews towards the use of PenPal Schools.

\subsection{Comparison of Results between March 2018 and May 2018 School Based Writing Assessment}

Based on the result in Table 1, it has found out that there is an improvement in their writing results. The number of students who score A and B have increased by 3 and by 5 respectively while the number of students who scored $C$ and $D$ both have reduced by 4 . Though the improvement is not tremendous, yet we must understand that there is no short cut to master the language in one month. It takes time and practice makes perfect.

Table 1. Comparison of results between March 2018 and May 2018.

\begin{tabular}{cccc}
\hline GRADE & MARCH 2018 & MAY 2018 & DIFFERENCES \\
\hline A $(80-100)$ & 1 & 4 & +3 \\
B $(65-79)$ & 5 & 10 & +5 \\
C $(50-64)$ & 14 & 10 & -4 \\
D $(40-49)$ & 10 & 6 & -4 \\
E (0 - 39) & 0 & 0 & 0 \\
\hline
\end{tabular}




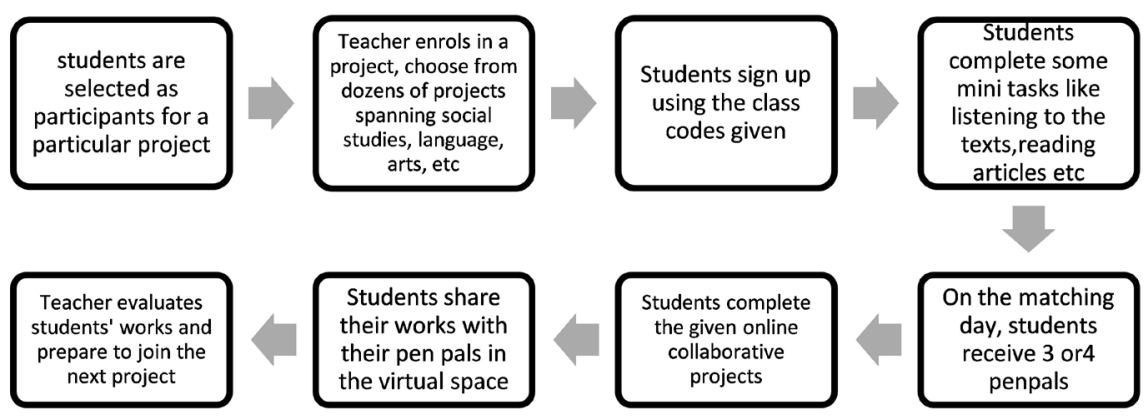

Figure 2. Research procedures of PenPal schools.

\subsection{Survey Results}

As mentioned in the earlier section, the investigation into the potential of using PenPal Schools in ESL writing classroom was based on a modified version of Unified Theory of Acceptance and Use of Technology (UTAUT) model. The report of the findings reveals the ESL learners' perception towards PenPal Schools though four key constructs of the UTAUT model, namely, 1) effort expectancy; 2) performance expectancy; 3) facilitating condition; and 4) behavioural intention.

As shown in Table 2, it was found that all constructs scored between 4.02 and 4.47. The mean score obtained for each of the constructs was; perception towards PenPal School 4.27, performance expectancy 4.02, effort expectancy 4.27, facilitating condition 4.32 and behavioural intention 4.47 . These indicate that the respondents rated behavioural intention as the highest, while performance expectancy as the lowest.

\section{1) Perception towards PenPal Schools}

Based on the result in Table 3, the findings indicated that the respondents had exhibited positive attitudes towards PenPal School as 22 participants (73.33\%) agreed that PenPal Schools is very interesting, in addition, 18 participants (60\%) strongly agree that PenPal Schools is more fun than the traditional writing classroom. Data also showed that majority $(>50 \%)$ of the respondents like watching the videos and reading the articles in PenPal Schools. This positive attitude towards PenPal Schools reveals that this online learning community is potential to be embedded as one of the options for a writing lesson. However, there is one participant who had found PenPal Schools not interesting. It is essential for this study to further elaborate on the reasons.

\section{2) Effort Expectancy}

Effort Expectancy is correlated to the degree of ease to use the proposed system or approach. So, based on the findings in Table 4, it can be concluded that PenPal Schools is easy to use and the instructions are clear and can be understood among young ESL learner. None of them (0\%) who perceived as being difficult to use.

\section{3) Performance Expectancy}

In term of teaching and learning, performance expectancy is the most impor- 
tant as it can reveal the user's belief on how useful a particular system is and how the performance will be enhanced. Based on the findings in Table 5, 17\% or $56.67 \%$ of the participants strongly believed that PenPal Schools could help them in learning English while another 11 participants (36.67\%) also agree with it. Moreover, PenPal Schools helped in increasing their interest to learn English with 25 of them $(83.33 \%)$ strongly agree or at least agree with the statement shown. Then, 18 of the participants realised that they could write longer and better in PenPal schools. This is indeed a highlight to attract more educators to try out PenPal Schools as we could realise many students have an aversion towards writing. So, this learning community could help in curbing this phenomenon. For listening and reading skills, both skills reveal positive results as more than half of the participants agree that PenPal schools could help them in both skills. The only shortcoming in PenPal Schools is in term of improving speaking skill as there were learners who disagree with the statement on improving speaking. Despite of the point on speaking skill, PenPal Schools is found out to be a potential learning community for learners to learn or practise their English in this era of 4.0 education. Overall, the findings in this section show that the ESL learners have positive attitude towards PenPal Schools.

\section{4) Facilitating Condition}

Life in the new millennium seems to be jet set fast. Based on the findings in Table 6, it had found out that majority of the participants do not face any technology related problems when they use PenPal Schools. 28 out of 30 participants (93.33\%) have resources that could help them to go online while there is only one participant $(3.33 \%)$ who faced problem in doing the task. Aids are available with 15 of them strongly agree, 8 of them agree and 7 have neutral attitude towards it.

\section{5) Behavioural intention to use PenPal Schools}

Based on the result in Table 7, it reveals that PenPal Schools is an interesting virtual classroom that had attracted young ESL learners as 19 participants (63.33\%) strongly agree that they will continue to use PenPal Schools while another 6 of them (20\%) agree with it as well. For the 5 participants who are unsure, it would be the educator's role to motivate them to use as social influence is another vital construct in UTAUT model.

Table 2. Mean Score for each constructs.

\begin{tabular}{cccc}
\hline CONSTRUCT & MIN & MAX & MEAN \\
\hline Perception towards PenPal Schools & 3.97 & 4.57 & 4.27 \\
Effort expectancy & 4.07 & 4.47 & 4.27 \\
Performance expectancy & 3.53 & 4.5 & 4.02 \\
Facilitating condition & 4.27 & 4.37 & 4.32 \\
Behavioural intention & 4.47 & 4.47 & 4.47 \\
\hline
\end{tabular}


Table 3. Perception towards the use of PenPal Schools in ESL classroom.

\begin{tabular}{|c|c|c|c|c|c|c|}
\hline & $\begin{array}{l}\text { Strongly } \\
\text { agree }\end{array}$ & Agree & Neutral & Disagree & $\begin{array}{l}\text { Strongly } \\
\text { disagree }\end{array}$ & Average \\
\hline $\begin{array}{l}\text { PenPal Schools is more fun } \\
\text { than the traditional classroom } \\
\text { instruction }\end{array}$ & $\begin{array}{c}18 \\
(60 \%)\end{array}$ & $\begin{array}{c}10 \\
(33.33 \%)\end{array}$ & $\begin{array}{c}2 \\
(6.67 \%)\end{array}$ & $\begin{array}{c}0 \\
(0 \%)\end{array}$ & $\begin{array}{c}0 \\
(0 \%)\end{array}$ & 4.53 \\
\hline $\begin{array}{l}\text { I like watching the lessons on } \\
\text { PenPal Schools }\end{array}$ & $\begin{array}{c}8 \\
(26.67 \%)\end{array}$ & $\begin{array}{c}17 \\
(56.67 \%)\end{array}$ & $5(16.67 \%)$ & $\begin{array}{c}0 \\
(0 \%)\end{array}$ & $\begin{array}{c}0 \\
(0 \%)\end{array}$ & 4.1 \\
\hline $\begin{array}{l}\text { I like reading the articles on } \\
\text { PenPal Schools }\end{array}$ & $\begin{array}{c}8 \\
(26.67 \%)\end{array}$ & $\begin{array}{c}13 \\
(43.33 \%)\end{array}$ & $\begin{array}{c}9 \\
(30 \%)\end{array}$ & $\begin{array}{c}0 \\
(0 \%)\end{array}$ & $\begin{array}{c}0 \\
(0 \%)\end{array}$ & 3.97 \\
\hline $\begin{array}{l}\text { PenPal Schools is very } \\
\text { interesting }\end{array}$ & $\begin{array}{c}22 \\
(73.33 \%)\end{array}$ & $\begin{array}{c}5 \\
(16.67 \%)\end{array}$ & $\begin{array}{c}2 \\
(6.67 \%)\end{array}$ & $\begin{array}{c}0 \\
(0 \%)\end{array}$ & $\begin{array}{c}1 \\
(3.33 \%)\end{array}$ & 4.57 \\
\hline
\end{tabular}

Table 4. How do you find PenPal Schools?

\begin{tabular}{|c|c|c|c|c|c|c|}
\hline & $\begin{array}{l}\text { Strongly } \\
\text { agree }\end{array}$ & Agree & Neutral & Disagree & $\begin{array}{l}\text { Strongly } \\
\text { disagree }\end{array}$ & Average \\
\hline $\begin{array}{l}\text { PenPal Schools } \\
\text { is easy to use }\end{array}$ & $\begin{array}{c}16 \\
(53.33 \%)\end{array}$ & $\begin{array}{c}12 \\
(40 \%)\end{array}$ & $\begin{array}{c}2 \\
(6.67 \%)\end{array}$ & $\begin{array}{c}0 \\
(0 \%)\end{array}$ & $\begin{array}{c}0 \\
(0 \%)\end{array}$ & 4.47 \\
\hline $\begin{array}{c}\text { The instructions in } \\
\text { PenPal Schools are clear }\end{array}$ & $\begin{array}{c}10 \\
(33.33 \%)\end{array}$ & $\begin{array}{c}12 \\
(40 \%)\end{array}$ & $\begin{array}{c}8 \\
(26.67 \%)\end{array}$ & $\begin{array}{c}0 \\
(0 \%)\end{array}$ & $\begin{array}{c}0 \\
(0 \%)\end{array}$ & 4.07 \\
\hline $\begin{array}{c}\text { The instructions in PenPal } \\
\text { Schools can be understood easily }\end{array}$ & $\begin{array}{c}10 \\
(33.33 \%)\end{array}$ & $\begin{array}{c}15 \\
(50 \%)\end{array}$ & $5(16.67 \%)$ & $\begin{array}{c}0 \\
(0 \%)\end{array}$ & $\begin{array}{c}0 \\
(0 \%)\end{array}$ & 4.17 \\
\hline
\end{tabular}

Table 5. Do you think that PenPal Schools is useful to help you in learning English?

\begin{tabular}{|c|c|c|c|c|c|c|}
\hline & $\begin{array}{l}\text { Strongly } \\
\text { agree }\end{array}$ & Agree & Neutral & Disagree & $\begin{array}{l}\text { Strongly } \\
\text { disagree }\end{array}$ & Average \\
\hline $\begin{array}{l}\text { PenPal Schools website } \\
\text { is useful for me to learn } \\
\text { English }\end{array}$ & $\begin{array}{c}17 \\
(56.67 \%)\end{array}$ & $\begin{array}{c}11 \\
36.67 \%)\end{array}$ & $\begin{array}{c}2 \\
(6.67 \%)\end{array}$ & $\begin{array}{c}0 \\
(0 \%)\end{array}$ & $\begin{array}{c}0 \\
(0 \%)\end{array}$ & 4.5 \\
\hline $\begin{array}{l}\text { PenPal Schools increases } \\
\text { my interest in learning } \\
\text { English }\end{array}$ & $\begin{array}{c}11 \\
(36.67 \%)\end{array}$ & $\begin{array}{c}14 \\
(46.67 \%)\end{array}$ & $\begin{array}{c}5 \\
(16.67 \%)\end{array}$ & $\begin{array}{c}0 \\
(0 \%)\end{array}$ & $\begin{array}{c}0 \\
(0 \%)\end{array}$ & 4.2 \\
\hline $\begin{array}{l}\text { PenPal Schools has } \\
\text { helped to improve my } \\
\text { listening skill }\end{array}$ & $\begin{array}{c}7 \\
(23.33 \%)\end{array}$ & $\begin{array}{c}11 \\
(36.67 \%)\end{array}$ & $\begin{array}{c}8 \\
(26.67 \%)\end{array}$ & $\begin{array}{c}4 \\
(13.33 \%)\end{array}$ & $\begin{array}{c}0 \\
(0 \%)\end{array}$ & 3.7 \\
\hline $\begin{array}{l}\text { PenPal Schools has } \\
\text { helped to improve my } \\
\text { speaking skill }\end{array}$ & $\begin{array}{c}7 \\
(23.33 \%)\end{array}$ & $\begin{array}{c}8 \\
(26.67 \%)\end{array}$ & $\begin{array}{c}9 \\
(30 \%)\end{array}$ & $\begin{array}{c}6 \\
(20 \%)\end{array}$ & $\begin{array}{c}0 \\
(0 \%)\end{array}$ & 3.53 \\
\hline $\begin{array}{l}\text { PenPal Schools has } \\
\text { helped to improve my } \\
\text { reading skill }\end{array}$ & $\begin{array}{c}11 \\
(36.67 \%)\end{array}$ & $\begin{array}{c}13 \\
(43.33 \%)\end{array}$ & $\begin{array}{c}6 \\
(20 \%)\end{array}$ & $\begin{array}{c}0 \\
(0 \%)\end{array}$ & $\begin{array}{c}0 \\
(0 \%)\end{array}$ & 4.17 \\
\hline $\begin{array}{l}\text { PenPal Schools has } \\
\text { helped to improve my } \\
\text { writing skill }\end{array}$ & $\begin{array}{c}11 \\
(36.67 \%)\end{array}$ & $\begin{array}{c}13 \\
(43.33 \%)\end{array}$ & $\begin{array}{c}5 \\
(16.67 \%)\end{array}$ & $\begin{array}{c}1 \\
(3.33 \%)\end{array}$ & $\begin{array}{c}0 \\
(0 \%)\end{array}$ & 4.13 \\
\hline $\begin{array}{l}\text { I can write longer in } \\
\text { PenPal Schools }\end{array}$ & $\begin{array}{c}7 \\
(23.33 \%)\end{array}$ & $\begin{array}{c}11 \\
(36.67 \%)\end{array}$ & $\begin{array}{c}11 \\
(36.67 \%)\end{array}$ & $\begin{array}{c}1 \\
(3.33 \%)\end{array}$ & $\begin{array}{c}0 \\
(0 \%)\end{array}$ & 3.8 \\
\hline $\begin{array}{l}\text { I can write better in } \\
\text { PenPal Schools }\end{array}$ & $\begin{array}{c}7 \\
(23.33 \%)\end{array}$ & $\begin{array}{c}11 \\
(36.67 \%)\end{array}$ & $\begin{array}{c}12 \\
(40 \%)\end{array}$ & $\begin{array}{c}0 \\
(0 \%)\end{array}$ & $\begin{array}{c}0 \\
(0 \%)\end{array}$ & 3.83 \\
\hline
\end{tabular}


Table 6. Do you face any problems when you use PenPal Schools?

\begin{tabular}{|c|c|c|c|c|c|c|}
\hline & Strongly agree & Agree & Neutral & Disagree & $\begin{array}{l}\text { Strongly } \\
\text { disagree }\end{array}$ & Average \\
\hline $\begin{array}{c}\text { I have } \mathrm{Wi}-\mathrm{Fi} \text {, computers } \\
\text { or laptops at home }\end{array}$ & $\begin{array}{c}15 \\
(50 \%)\end{array}$ & $\begin{array}{c}13 \\
(43.33 \%)\end{array}$ & $\begin{array}{c}1 \\
(3.33 \%)\end{array}$ & $\begin{array}{c}0 \\
(0 \%)\end{array}$ & $\begin{array}{c}1 \\
(3.33 \%)\end{array}$ & 4.37 \\
\hline $\begin{array}{l}\text { Teachers are available } \\
\text { to help me on the } \\
\text { problems I face in } \\
\text { PenPal School }\end{array}$ & $\begin{array}{c}15 \\
(50 \%)\end{array}$ & $8(26.67 \%)$ & $7(23.33 \%)$ & $\begin{array}{c}0 \\
(0 \%)\end{array}$ & $\begin{array}{c}0 \\
(0 \%)\end{array}$ & 4.27 \\
\hline
\end{tabular}

Table 7. Will you continue to use PenPal Schools?

\begin{tabular}{|c|c|c|c|c|c|c|}
\hline & $\begin{array}{c}\text { Strongly } \\
\text { agree }\end{array}$ & Agree & Neutral & Disagree & $\begin{array}{l}\text { Strongly } \\
\text { disagree }\end{array}$ & Average \\
\hline $\begin{array}{l}\text { I will continue learning } \\
\text { English using PenPal } \\
\text { Schools in the future. }\end{array}$ & $\begin{array}{c}19 \\
(63.33 \%)\end{array}$ & $\begin{array}{c}6 \\
(20 \%)\end{array}$ & $5(16.67 \%)$ & $\begin{array}{c}0 \\
(0 \%)\end{array}$ & $\begin{array}{c}0 \\
(0 \%)\end{array}$ & 4.47 \\
\hline
\end{tabular}

\subsection{Learner Responses towards the Use of PenPal Schools}

It is undeniable that writing is most students would perceive writing skill as the hardest if compared to listening, reading and speaking. Many issues like first language interference, less supportive classroom climate, failure in seeing the value of the learning content, lack of vocabulary to write and lack of authenticity in the writing task conducted are the main problems that Malaysian ESL learners faced. So, based on the responses from the semi-structured interviews, there are two main strengths to this Pen Pal Schools project. Firstly, this project has embedded a purposive writing element in it. The students were found out to write in their full effort as they knew that they were sending it to a real person. Quoted from one of the respondents, Chee Ken,

"It is a website that I can make contact with others and learn English at the same time".

"Yes, I do. I found that there are a lot of interesting and good things and I can spend a lot of time with my pen pals and get our friendship closer."

Since the learners have a purpose in writing. It had found out to give the students a great positive stimulation where it triggers the students' desire to improve their writing skills as well as to learn more vocabulary. Therefore, we know that active learning had taken place automatically and is not by force. PuiTeng pointed out that:

"Yes, at first I can't understand all the words there and now I know the meaning very well. Yes, I can write more now."

Besides that, this PenPal schools project also provides the learners real world exploration. They were writing to authentic audience, in addition, some of them are native speakers. It fulfils the 21 st century classroom concept as the classroom environment is not rigid and the lesson was being carried out outside the classroom. The students had high motivation to write. It has even reduced their an- 
xiety towards writing. Yen specifically stated that:

"Yes, I am having a good time using PenPal Schools and I can make friends around the world, which I actually never got a chance to do that before this."

The next section would conclude this paper and further discuss the implications towards teaching and learning in the ESL classroom.

\section{Conclusion and Implication}

This paper aimed to describe the potential of using PenPal Schools' learning community to improve students' writing. Overall, learning to write by involving oneself in an online collaboration project with pen pals around the world is an awesome experience. So, utilising an authentic material together with native speakers in a virtual ESL classroom is really a fun and engaging learning experience. PenPal School is indeed a dynamic tool that enables students to create a sense of community inside and outside the classroom. It is one of the great alternatives for students to practise writing using the language they learn and also promote intercultural communication with learners around the world. Moreover, this project had generated a lot of excitement as they were engaged in authentic language exchanges with authentic audience and particularly some of them were native speakers. Thus, this authentic material is recommended and it is indeed very useful in our teaching and learning process.

Although the present study suggests that the PenPal School is beneficial to the pupils, there are still some other areas that need to be further studied. It is wise for future research to have a larger sample and involve students from all over Malaysia, especially the rural areas. Since there are listening texts and reading texts in PenPal School, it would be great to further study on its effects towards the listening and reading skills among ESL learners. Then, since speaking skill is hardly practiced using this, it would be best if future research could discuss on the challenges and of course ways to overcome this shortcoming.

In conclusion, using an authentic online material like PenPal Schools had successfully created a ripple in the field of language learning. From this study, aspects of PenPal Schools are found out to be very potential in promoting active and effective learning. In addition, all materials in PenPal Schools are aligned to Common Core, TEKS, and IB standard which are aimed to ensure positive learning outcomes. Since the quality of writing had improved tremendously, it is time for all the educators to embrace this authentic material and help our students to develop language skills outside the classroom.

\section{Implications for Teaching and Learning}

From the study above, utilizing an authentic online material like PenPal Schools in the ESL classroom had shown that the quality of students' writing had improved. The engagement for learners all around the world in a dynamic and collaborative virtual classroom like PenPal Schools is indeed positive. In addition, it fulfills the aspects in the learning pyramid and students are learning in a virtual 
classroom with authentic audience which is about the same age as them. In term of impact towards the educators, it is believed that the use of PenPal Schools could rediscover some basic approaches in ways of teaching writing that had been neglected for some time. It is also undeniable that writing tasks that deal with meaningful, engaging and real life situations are indeed better than conventional, artificial as well as decontextualised exercises.

Priority should be set by teachers after they have weighed out the pros and cons if or when using this educational tool. If teachers could allocate more time to conduct this type of activity, this will surely breathe a new life in the Malaysian ESL writing classrooms. Learning starts with engagement. It is hoped that this type of global project-based learning could help to shed new light on the era of 4.0 education.

\section{Conflicts of Interest}

The authors declare no conflicts of interest regarding the publication of this paper.

\section{References}

Abdullah, A., \& Peters, R. F. (2015). Malaysia's Post-PISA2012 Direction. International Journal of Culture and History, 1, 15-20.

Ajjan, H., \& Hartshorne, R. (2008). Investigating Faculty Decisions to Adopt Web 2.0 Technologies: Theory and Empirical Tests. The Internet and Higher Education, 11, 71-80. https://doi.org/10.1016/j.iheduc.2008.05.002

Austin, M. S., \& Harkins, D. A. (2008). Assessing Change: Can Organizational Learning "Work" for Schools? The Learning Organization, 15, 105-125.

https://doi.org/10.1108/09696470810852302

Burk, J. (1989). Pen Pals: A Beneficial Partnership.

Gerstein, J. (2014). Moving from Education 1.0 through Education 2.0 towards Education 3.0 .

Goldie, J. G. S. (2016). Connectivism: A Knowledge Learning Theory for the Digital Age? Medical Teacher, 38, 1064-1069. https://doi.org/10.3109/0142159X.2016.1173661

Ien, L. K., Yunus, M. M., \& Embi, M. A. (2017). Build Me Up: Overcoming Writing Problems among Pupils in a Rural Primary School in Belaga, Sarawak, Malaysia. Jurnal Pendidikan Humaniora, 5, 1-7. https://doi.org/10.17977/um030v5i12017p001

Mohamad, M., Ghazali, N., \& Hashim, H. (2018). Secondary School Students' Perceptions on the Use of Google+ towards Improving ESL Writing Skills. International Journal of Emerging Technologies in Learning (iJET), 13, 224-238. https://doi.org/10.3991/ijet.v13i09.8479

Pitura, J., \& Monika, B. K. (2018). Learning English While Exploring the National Cultural Heritage: Technology-Assisted Project-Based Language Learning in an Upper-Secondary School. Teaching English with Technology, 18, 37-52.

Puncreobutr, V. (2016). Education 4.0: New Challenge of Learning. St. Theresa Journal of Humanities and Social Sciences, 2, No. 2.

Venkatesh, V., Morris, M. G., Davis, G. B., \& Davis, F. D. (2003). User Acceptance of Information Technology: Toward a Unified View. MIS Quarterly, 27, 425-478.

https://doi.org/10.2307/30036540 
Yunus, M. M. (2018). Innovation in Education and Language Learning in 21st Century. Journal of Sustainable Development Education and Research, 2, 33-34.

Yunus, M. M., \& Chien, C. H. (2016). The Use of Mind Mapping Strategy in Malaysian University English Test (MUET) Writing. Creative Education, 7, 619-626. https://doi.org/10.4236/ce.2016.74064

Yunus, M. M., Nordin, N., Salehi, H., Embi, M. A., \& Salehi, Z. (2013). The Use of Information and Communication Technology (ICT) in Teaching ESL Writing Skills. English Language Teaching, 6, 1-8. https://doi.org/10.5539/elt.v6n7p1

Yunus, M. M., Salehi, H., \& Amini, M. (2016). Impact of Using CALL on Iranian EFL Learners' Vocabulary Knowledge. English Language Teaching, 9, 173-187.

https://doi.org/10.5539/elt.v9n1p173 